\title{
Electronic structures of trans-dioxometal complexes
}

\author{
Patrick Hummel, Jay R. Winkler and Harry B. Gray*
}

Received 30th August 2005, Accepted 10th October 2005

First published as an Advance Article on the web 4th November 2005

DOI: 10.1039/b512299f

We have employed computational methods based on density functional theory to elucidate the effects of equatorial ligands on the electronic structures of trans-dioxometal complexes. In complexes with ammine ( $\sigma$-only) equatorial donors, the ${ }^{1} \mathrm{~A}_{1 \mathrm{~g}}\left(\mathrm{~b}_{2 \mathrm{~g}}\right)^{2} \rightarrow{ }^{1} \mathrm{E}_{\mathrm{g}}\left(\mathrm{b}_{2 \mathrm{~g}}\right)^{1}\left(\mathrm{e}_{\mathrm{g}}\right)^{1}$ excitation energy increases with metal oxidation state: $\mathrm{Mo}(\mathrm{IV})<\mathrm{Tc}(\mathrm{v})<\mathrm{Ru}(\mathrm{VI})$ and $\mathrm{W}(\mathrm{IV})<\mathrm{Re}(\mathrm{v})<\mathrm{Os}(\mathrm{VI})$. Increasing transition energies are attributed to enhanced oxometal $\pi$-donor interactions in the higher valent central metals. But in complexes with cyanide equatorial donors, the ${ }^{1} \mathrm{~A}_{1 \mathrm{~g}}\left(\mathrm{~b}_{2 \mathrm{~g}}\right)^{2} \rightarrow{ }^{1} \mathrm{E}_{\mathrm{g}}\left(\mathrm{b}_{2 \mathrm{~g}}\right)^{1}\left(\mathrm{e}_{\mathrm{g}}\right)^{1}$ energy remains roughly independent of metal oxidation state, likely owing to the compensating increased $\pi$-donation from the $\pi(\mathrm{CN})$ orbitals to the metal $d_{\mathrm{xy}}$ orbitals as the oxidation state of the metal increases.

\section{Introduction}

Multiple bonds stabilize high oxidation states of oxometal units. The tetragonal $d^{1}$ and $d^{2}$ oxometal complexes, often incorrectly formulated as $\mathrm{M}=\mathrm{O}$ instead of $\mathrm{M} \equiv \mathrm{O}$, have been studied for over 40 years. ${ }^{1-12}$ Of special interest here are trans-dioxometal complexes of the form $\left[\mathrm{MO}_{2} \mathrm{~L}_{4}\right]^{z}$ (Fig. 1). We consider $\mathrm{M}=\mathrm{Mo}$, Tc, Ru, W, Re, Os; $\mathrm{L}=\mathrm{NH}_{3}, z=2+,+, 0 ; \mathrm{L}=\mathrm{CN}^{-}, z=2-$, $3-, 4-$. The ground state is ${ }^{1} \mathrm{~A}_{1 \mathrm{~g}}\left(\mathrm{~b}_{2 \mathrm{~g}}\right)^{2}$, with a well established ligand field splitting pattern: $b_{2 g}(x y)<e_{g}(x z, y z)<b_{1 g}\left(x^{2}-y^{2}\right)<$ $\mathrm{a}_{1 \mathrm{~g}}\left(\mathrm{z}^{2}\right)$. The lowest lying electronic excitations involve transitions from the nonbonding $b_{2 g}$ orbital to a $\pi$-antibonding $e_{g}$ orbital. The ${ }^{1} \mathrm{~A}_{1 \mathrm{~g}}\left(\mathrm{~b}_{2 \mathrm{~g}}\right)^{2} \rightarrow{ }^{1} \mathrm{E}_{\mathrm{g}}\left(\mathrm{b}_{2 \mathrm{~g}}\right)^{1}\left(\mathrm{e}_{\mathrm{g}}\right)^{1}$ excitation and the spin-forbidden ${ }^{1} \mathrm{~A}_{1 \mathrm{~g}}\left(\mathrm{~b}_{2 \mathrm{~g}}\right)^{2} \rightarrow{ }^{3} \mathrm{E}_{\mathrm{g}}\left(\mathrm{b}_{2 \mathrm{~g}}\right)^{1}\left(\mathrm{e}_{\mathrm{g}}\right)^{1}$ transition are distinct features in the absorption spectra of trans-dioxometal complexes. Radiative decay of the triplet excited state is often prominent as well. ${ }^{4-6}$

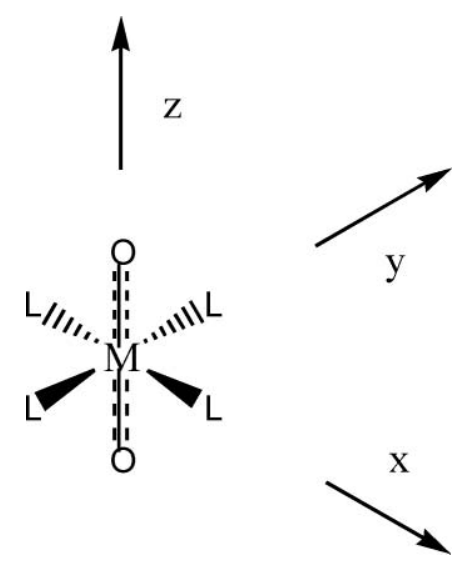

Fig. 1 The structure of the $\left[\mathrm{MO}_{2} \mathrm{~L}_{4}\right]^{z}$ complexes in question.

We now report a systematic investigation of the electronic structures of $d^{2}$-trans-dioxometal complexes. In particular, we use density functional theory (DFT) and time-dependent density functional theory (TDDFT) to analyze the effects of equatorial ligand interactions on the $\Delta=E\left[\mathrm{e}_{\mathrm{g}}(\mathrm{xz}, \mathrm{yz})\right]-E\left[\mathrm{~b}_{2 \mathrm{~g}}(\mathrm{xy})\right]$ energy

California Institute of Technology, 1200 E. California Blvd., Mail Code 139-74, Pasadena, CA 91125, USA. E-mail: hbgray@caltech.edu gap as a function of metal oxidation state. For $\left[\mathrm{MO}_{2}\left(\mathrm{NH}_{3}\right)_{4}\right]^{z}$, we note a general increase in $\Delta$ with increase in metal oxidation state: $\mathrm{Mo}(\mathrm{IV})<\mathrm{Tc}(\mathrm{v})<\mathrm{Ru}(\mathrm{VI})$ and $\mathrm{W}(\mathrm{IV})<\operatorname{Re}(\mathrm{v})<\mathrm{Os}(\mathrm{VI})$. For $\left[\mathrm{MO}_{2}(\mathrm{CN})_{4}\right]^{z}$ the values of $\Delta$ remain roughly independent of the oxidation state of the central metal.

\section{Computational methods}

All calculations reported herein were performed with the TURBOMOLE program package for ab initio electronic structure calculations. ${ }^{13}$ We used the TZVP basis set $^{14}$ for all atoms in calculating the properties of these complexes. For each metal, we used the effective core potentials given by Andrae et al. ${ }^{15}$ to account for relativistic effects. We performed four different DFT calculations for each complex, each using a different exchangecorrelation functional selected from B3LYP, PBE, BP86, and BLYP. ${ }^{16-24}$ The calculations were done using the COSMO continuum solvation model ${ }^{25}$ with dielectric constant 37.5. Each calculation was performed with an $\mathrm{m} 3$ gridsize. ${ }^{26}$ The geometry of each complex was optimized using TURBOMOLE's JOBEX program with generalized internal coordinates ${ }^{27}$ and the corresponding STATPT module. Energies of well-converged groundstate molecular orbitals were calculated with the DSCF module for semi-direct self-consistent-field evaluation. We then used these ground-state molecular orbitals to calculate the energies of the lowest-lying singlet $\rightarrow$ singlet transitions with the ESCF package for full TDDFT calculations. ${ }^{28,29}$ We have previously used similar methods in TURBOMOLE successfully to investigate the electronic structures of various inorganic complexes. ${ }^{30-32}$

\section{Results and discussion}

The calculated ground-state bond distances and ${ }^{1} \mathrm{~A}_{1 \mathrm{~g}}\left(\mathrm{~b}_{2 \mathrm{~g}}\right)^{2} \rightarrow$ ${ }^{1} \mathrm{E}_{\mathrm{g}}\left(\mathrm{b}_{2 \mathrm{~g}}\right)^{1}\left(\mathrm{e}_{\mathrm{g}}\right)^{1}$ excitation energies for twelve $d^{2}$-trans-dioxometal complexes are in good agreement with experiment (Tables 15). ${ }^{6,33-38}$ The overall performance of the four exchange-correlation functionals is roughly the same. For the $\left[\mathrm{MO}_{2}\left(\mathrm{NH}_{3}\right)_{4}\right]^{z}$ complexes, the experimental excitation energies are closest to those calculated with PBE, BP86, and BLYP. For $\left[\mathrm{MO}_{2}(\mathrm{CN})_{4}\right]^{z}$, the best results are obtained with B3LYP. 
Table 1 Metal-oxygen distances ( $\AA$ ) from calculations and crystal structures. ${ }^{33-38}$ For $\left[\mathrm{MO}_{2}\left(\mathrm{NH}_{3}\right)_{4}\right]^{z}$ complexes, we give experimental values for the corresponding $\left[\mathrm{MO}_{2}(\mathrm{en})_{2}\right]^{z}$ complexes

\begin{tabular}{llllll}
\hline & Expt & B3LYP & B-LYP & BP86 & PBE \\
\hline$\left[\mathrm{MoO}_{2}\left(\mathrm{NH}_{3}\right)_{4}\right]$ & & 1.833 & 1.852 & 1.842 & 1.843 \\
{$\left[\mathrm{TcO}_{2}\left(\mathrm{NH}_{3}\right)_{4}\right]^{+}$} & 1.747 & 1.763 & 1.787 & 1.777 & 1.777 \\
{$\left[\mathrm{RuO}_{2}\left(\mathrm{NH}_{3}\right)_{4}\right]^{2+}$} & & 1.724 & 1.752 & 1.741 & 1.741 \\
{$\left[\mathrm{WO}_{2}\left(\mathrm{NH}_{3}\right)_{4}\right]^{+}$} & & 1.855 & 1.873 & 1.863 & 1.862 \\
{$\left[\mathrm{ReO}_{2}\left(\mathrm{NH}_{3}\right)_{4}\right]^{+}$} & 1.765 & 1.790 & 1.812 & 1.803 & 1.803 \\
{$\left[\mathrm{OsO}_{2}\left(\mathrm{NH}_{3}\right)_{4}\right]^{++}$} & 1.74 & 1.752 & 1.777 & 1.768 & 1.768 \\
{$\left[\mathrm{MoO}_{2}(\mathrm{CN})_{4}\right]^{]_{-}}$} & 1.834 & 1.844 & 1.867 & 1.857 & 1.856 \\
{$\left[\mathrm{TcO}_{2}(\mathrm{CN})_{4}\right]^{3-}$} & & 1.779 & 1.805 & 1.795 & 1.795 \\
{$\left[\mathrm{RuO}_{2}(\mathrm{CN})_{4}\right]^{2-}$} & & 1.740 & 1.771 & 1.760 & 1.760 \\
{$\left[\mathrm{WO}_{2}(\mathrm{CN})_{4}\right]^{4-}$} & 1.842 & 1.866 & 1.886 & 1.875 & 1.875 \\
{$\left[\mathrm{ReO}_{2}(\mathrm{CN})_{4}\right]^{3-}$} & 1.781 & 1.806 & 1.830 & 1.819 & 1.818 \\
{$\left[\mathrm{OsO}_{2}(\mathrm{CN})_{4}\right]^{--}$} & 1.75 & 1.767 & 1.796 & 1.786 & 1.786 \\
\hline
\end{tabular}

Table 2 Metal-nitrogen $\left(\mathrm{NH}_{3}\right)$ and metal-carbon $(\mathrm{CN})$ distances $(\AA)$ from calculations and crystal structures. ${ }^{33-38}$ For $\left[\mathrm{MO}_{2}\left(\mathrm{NH}_{3}\right)_{4}\right]^{z}$ complexes, we give experimental values for the corresponding $\left[\mathrm{MO}_{2}(\mathrm{en})_{2}\right]^{z}$ complexes

\begin{tabular}{llllll}
\hline & Expt & B3LYP & B-LYP & BP86 & PBE \\
\hline$\left[\mathrm{MoO}_{2}\left(\mathrm{NH}_{3}\right)_{4}\right]$ & & 2.303 & 2.322 & 2.287 & 2.283 \\
{$\left[\mathrm{TcO}_{2}\left(\mathrm{NH}_{3}\right)_{4}\right]^{+}$} & 2.158 & 2.214 & 2.236 & 2.205 & 2.201 \\
{$\left[\mathrm{RuO}_{2}\left(\mathrm{NH}_{3}\right)_{4}\right]^{2+}$} & & 2.153 & 2.182 & 2.155 & 2.152 \\
{$\left[\mathrm{WO}_{2}\left(\mathrm{NH}_{3}\right)_{4}\right]^{+}$} & & 2.304 & 2.320 & 2.288 & 2.284 \\
{$\left[\mathrm{ReO}_{2}\left(\mathrm{NH}_{3}\right)_{4}\right]^{+}$} & 2.162 & 2.222 & 2.224 & 2.216 & 2.213 \\
{$\left[\mathrm{OsO}_{2}\left(\mathrm{NH}_{3}\right)_{4}\right]^{2+}$} & 2.11 & 2.167 & 2.193 & 2.169 & 2.164 \\
{$\left[\mathrm{MoO}_{2}(\mathrm{CN})_{4}\right]^{4-}$} & 2.220 & 2.229 & 2.228 & 2.201 & 2.198 \\
{$\left[\mathrm{TcO}_{2}(\mathrm{CN})_{4}\right]^{3-}$} & & 2.170 & 2.176 & 2.148 & 2.145 \\
{$\left[\mathrm{RuO}_{2}(\mathrm{CN})_{4}\right]^{2-}$} & & 2.124 & 2.145 & 2.113 & 2.110 \\
{$\left[\mathrm{WO}_{2}(\mathrm{CN})_{4}\right]^{4-}$} & 2.177 & 2.224 & 2.226 & 2.202 & 2.198 \\
{$\left[\mathrm{ReO}_{2}(\mathrm{CN})_{4}\right]^{3-}$} & 2.124 & 2.178 & 2.181 & 2.160 & 2.157 \\
{$\left[\mathrm{OsO}_{2}(\mathrm{CN})_{4}\right]^{2-}$} & & 2.139 & 2.151 & 2.128 & 2.125 \\
\hline
\end{tabular}

Table 3 Carbon-nitrogen distances from calculations and crystal structure $^{36}(\AA)$

\begin{tabular}{llllll}
\hline & Expt & B3LYP & B-LYP & BP86 & PBE \\
\hline$\left[\mathrm{MoO}_{2}(\mathrm{CN})_{4}\right]^{4-}$ & & 1.169 & 1.181 & 1.183 & 1.183 \\
{$\left[\mathrm{TcO}_{2}(\mathrm{CN})_{4}\right]^{3-}$} & & 1.162 & 1.174 & 1.175 & 1.175 \\
{$\left[\mathrm{RuO}_{2}(\mathrm{CN})_{4}\right]^{2-}$} & & 1.157 & 1.169 & 1.169 & 1.169 \\
{$\left[\mathrm{WO}_{2}(\mathrm{CN})_{4}\right]^{4-}$} & & 1.169 & 1.182 & 1.183 & 1.183 \\
{$\left[\mathrm{ReO}_{2}(\mathrm{CN})_{4}\right]^{3-}$} & 1.156 & 1.162 & 1.174 & 1.175 & 1.175 \\
{$\left[\mathrm{OsO}_{2}(\mathrm{CN})_{4}\right]^{2-}$} & & 1.156 & 1.168 & 1.169 & 1.169 \\
\hline
\end{tabular}

Table 5 Calculated and experimental ${ }^{6}$ energies of the ${ }^{1} A_{1 g}\left(b_{2 g}\right)^{2} \rightarrow$ ${ }^{1} \mathrm{E}_{\mathrm{g}}\left(\mathrm{b}_{2 \mathrm{~g}}\right)^{1}\left(\mathrm{e}_{\mathrm{g}}\right)^{1}$ excitation $(\mathrm{eV})$ for various $d^{2}$-trans-dioxometal complexes. For $\left[\mathrm{TcO}_{2}\left(\mathrm{NH}_{3}\right)_{4}\right]^{+}$and $\left[\mathrm{ReO}_{2}\left(\mathrm{NH}_{3}\right)_{4}\right]^{+}$, we give experimental values for $\left[\mathrm{TcO}_{2}(\mathrm{en})_{2}\right]^{+}$and $\left[\mathrm{ReO}_{2}(\mathrm{en})_{2}\right]^{+}$. For cyanide complexes, we give values for spectra measured in crystals, as protic solvents strongly affect excitation energies

\begin{tabular}{llllll}
\hline & Expt & B3LYP & B-LYP & BP86 & PBE \\
\hline$\left[\mathrm{MoO}_{2}\left(\mathrm{NH}_{3}\right)_{4}\right]$ & & 2.33 & 2.27 & 2.28 & 2.26 \\
{$\left[\mathrm{TcO}_{2}\left(\mathrm{NH}_{3}\right)_{4}\right]^{+}$} & 2.53 & 2.71 & 2.56 & 2.58 & 2.57 \\
{$\left[\mathrm{RuO}_{2}\left(\mathrm{NH}_{3}\right)_{4}\right]^{2+}$} & 2.73 & 3.00 & 2.78 & 2.82 & 2.81 \\
{$\left[\mathrm{WO}_{2}\left(\mathrm{NH}_{3}\right)_{4}\right]$} & & 2.55 & 2.47 & 2.49 & 2.48 \\
{$\left[\mathrm{ReO}_{2}\left(\mathrm{NH}_{3}\right)_{4}\right]^{+}$} & 2.83 & 2.93 & 2.79 & 2.81 & 2.80 \\
{$\left[\mathrm{OsO}_{2}\left(\mathrm{NH}_{3}\right)_{4}\right]^{2+}$} & & 3.25 & 3.02 & 3.06 & 3.06 \\
{$\left[\mathrm{MoO}_{2}(\mathrm{CN})_{4}\right]^{4-}$} & & 2.64 & 2.51 & 2.59 & 2.59 \\
{$\left[\mathrm{TcO}_{2}(\mathrm{CN})_{4}\right]^{3-}$} & & 2.71 & 2.51 & 2.58 & 2.58 \\
{$\left[\mathrm{RuO}_{2}(\mathrm{CN})_{4}\right]^{2-}$} & & 2.50 & 2.06 & 2.12 & 2.12 \\
{$\left[\mathrm{WO}_{2}(\mathrm{CN})_{4}\right]^{4-}$} & & 2.85 & 2.67 & 2.73 & 2.74 \\
{$\left[\mathrm{ReO}_{2}(\mathrm{CN})_{4}\right]^{3-}$} & 3.17 & 2.96 & 2.72 & 2.80 & 2.80 \\
{$\left[\mathrm{OsO}_{2}(\mathrm{CN})_{4}\right]^{2-}$} & 2.98 & 2.80 & 2.36 & 2.41 & 2.42 \\
\hline & & & & &
\end{tabular}

As the oxidation state of the central metal atom increases, the $\mathrm{e}_{\mathrm{g}}(\mathrm{xz}, \mathrm{yz})$ orbitals become more $\pi$-antibonding, owing to greater oxometal $\pi$-donor interactions. It follows that we expect a corresponding increase in the energies of the ${ }^{1} \mathrm{~A}_{1 \mathrm{~g}}\left(\mathrm{~b}_{2 \mathrm{~g}}\right)^{2} \rightarrow{ }^{1} \mathrm{E}_{\mathrm{g}}\left(\mathrm{b}_{2 \mathrm{~g}}\right)^{1}\left(\mathrm{e}_{\mathrm{g}}\right)^{1}$ excitations. This increase is observed for $\left[\mathrm{MO}_{2}\left(\mathrm{NH}_{3}\right)_{4}\right]^{z}$ complexes, but not for $\left[\mathrm{MO}_{2}(\mathrm{CN})_{4}\right]^{z}$ complexes, where the excitation energies remain roughly constant. Clearly for $\left[\mathrm{MO}_{2}(\mathrm{CN})_{4}\right]^{z}$ there is some other effect that causes significant changes in the relative energies of the $\mathrm{b}_{2 \mathrm{~g}}(\mathrm{xy})$ and $\mathrm{e}_{\mathrm{g}}(\mathrm{xz}, \mathrm{yz})$ orbitals.

To probe this effect, we analyze average changes in orbital energies per unit increase in the charge of the central metal. The average change in $E\left[\mathrm{e}_{\mathrm{g}}(\mathrm{xz}, \mathrm{yz})\right]$ is $-2.78 \mathrm{eV}$ for $\left[\mathrm{MO}_{2}\left(\mathrm{NH}_{3}\right)_{4}\right]^{2}$, and $-2.26 \mathrm{eV}$ for $\left[\mathrm{MO}_{2}(\mathrm{CN})_{4}\right]^{z}$. For $E\left[\mathrm{~b}_{2 \mathrm{~g}}(\mathrm{xy})\right]$, the average change is $-2.89 \mathrm{eV}$ for $\left[\mathrm{MO}_{2}\left(\mathrm{NH}_{3}\right)_{4}\right]^{z}$ and $-2.10 \mathrm{eV}$ for $\left[\mathrm{MO}_{2}(\mathrm{CN})_{4}\right]^{z}$. Consistent with the trends in energies of the ${ }^{1} \mathrm{~A}_{1 \mathrm{~g}}\left(\mathrm{~b}_{2 \mathrm{~g}}\right)^{2} \rightarrow$ ${ }^{1} \mathrm{E}_{\mathrm{g}}\left(\mathrm{b}_{2 \mathrm{~g}}\right)^{1}\left(\mathrm{e}_{\mathrm{g}}\right)^{1}$ excitation, the average change in $E\left[\mathrm{e}_{\mathrm{g}}(\mathrm{xz}, \mathrm{yz})\right]$ is greater (less negative) than the average change in $E\left[\mathrm{~b}_{2 \mathrm{~g}}(\mathrm{xy})\right]$ for $\left[\mathrm{MO}_{2}\left(\mathrm{NH}_{3}\right)_{4}\right]^{z}$, but the average change in $\mathrm{E}\left[\mathrm{b}_{2 \mathrm{~g}}(\mathrm{xy})\right]$ is greater than the average change in $E\left[\mathrm{e}_{\mathrm{g}}(\mathrm{xz}, \mathrm{yz})\right]$ for $\left[\mathrm{MO}_{2}(\mathrm{CN})_{4}\right]^{z}$. The energy changes cited here do not vary strongly with exchange-correlation functional or central metal.

The ${ }^{1} \mathrm{E}_{\mathrm{g}}\left(\mathrm{b}_{2 \mathrm{~g}}\right)^{1}\left(\mathrm{e}_{\mathrm{g}}\right)^{1}$ excited state of a $\left[\mathrm{MO}_{2}(\mathrm{CN})_{4}\right]^{z}$ complex is stabilized by backbonding from the metal $\left(d_{\mathrm{xz}}, d_{\mathrm{yz}}\right)$ orbitals to the cyanide $\pi^{*}$ orbitals. Thus one possible explanation for the differing trends in $\left[\mathrm{MO}_{2}\left(\mathrm{NH}_{3}\right)_{4}\right]^{z}$ and $\left[\mathrm{MO}_{2}(\mathrm{CN})_{4}\right]^{z}$ is that greater bonding overlap between the $\left(d_{\mathrm{xz}}, d_{\mathrm{yz}}\right)$ and $\pi^{*}(\mathrm{CN})$ orbitals is achieved

Table 4 Calculated energies of $b_{2 g}(x y) / e_{g}(x z, y z)$ orbitals $(e V)$

\begin{tabular}{lllll}
\hline & B3LYP & B-LYP & BP86 & PBE \\
\hline$\left[\mathrm{MoO}_{2}\left(\mathrm{NH}_{3}\right)_{4}\right]$ & $-3.66 / 0.50$ & $-2.30 /-0.31$ & $-2.41 /-0.43$ & $-2.30 /-0.33$ \\
{$\left[\mathrm{TcO}_{2}\left(\mathrm{NH}_{3}\right)_{4}\right]^{+}$} & $-6.79 /-2.20$ & $-5.16 /-2.88$ & $-5.26 /-2.99$ & $-5.13 /-2.88$ \\
{$\left[\mathrm{RuO}_{2}\left(\mathrm{NH}_{3}\right)_{4}\right]^{2+}$} & $-10.11 /-5.33$ & $-8.38 / 5.88$ & $-8.52 /-6.00$ & $-8.40 /-5.89$ \\
{$\left[\mathrm{WO}_{2}\left(\mathrm{NH}_{3}\right)_{4}\right]^{2}$} & $-3.21 / 0.89$ & $-2.03 / 0.20$ & $-2.17 / 0.06$ & $-2.05 / 0.17$ \\
{$\left[\mathrm{ReO}_{2}\left(\mathrm{NH}_{3}\right)_{4}\right]^{+}$} & $-6.25 /-1.59$ & $-4.82 /-2.31$ & $-4.96 /-2.44$ & $-4.83 /-2.32$ \\
{$\left[\mathrm{OsO}_{2}\left(\mathrm{NH}_{3}\right)_{4}\right]^{2+}$} & $-9.65 /-4.66$ & $-8.03 /-5.26$ & $-8.18 /-5.40$ & $-8.06 /-5.29$ \\
{$\left[\mathrm{MoO}_{2}(\mathrm{CN})_{4}\right]^{4-}$} & $-3.33 / 0.88$ & $-2.34 / 0.01$ & $-2.63 /-0.22$ & $-2.50 /-0.08$ \\
{$\left[\mathrm{TcO}_{2}(\mathrm{CN})_{4}\right]^{3-}$} & $-5.67 /-1.30$ & $-4.34 /-2.04$ & $-4.60 /-2.24$ & $-4.46 /-2.10$ \\
{$\left[\mathrm{RuO}_{2}(\mathrm{CN})_{4}\right]^{2-}$} & $-7.96 /-4.02$ & $-6.51 /-4.60$ & $-6.74 /-4.78$ & $-6.60 /-4.64$ \\
{$\left[\mathrm{WO}_{2}(\mathrm{CN})_{4}\right]^{-}$} & $-3.11 / 1.14$ & $-2.24 / 0.30$ & $-2.55 / 0.05$ & $-2.42 / 0.18$ \\
{$\left[\mathrm{ReO}_{2}(\mathrm{CN})_{4}\right]^{3-}$} & $-5.33 /-0.87$ & $-4.18 /-1.63$ & $-4.45 /-1.83$ & $-4.31 /-1.69$ \\
{$\left[\mathrm{OsO}_{2}(\mathrm{CN})_{4}\right]^{2-}$} & $-7.64 /-3.45$ & $-6.29 /-4.07$ & $-6.53 /-4.27$ & $-6.40 /-4.13$ \\
\hline
\end{tabular}


as metal oxidation state increases. However, our calculations are not in accord with this explanation. For $\left[\mathrm{MO}_{2}\left(\mathrm{NH}_{3}\right)_{4}\right]^{2}$, the average change in $\mathrm{E}\left[\mathrm{e}_{\mathrm{g}}(\mathrm{xz}, \mathrm{yz})\right]$ per unit increase in the charge of the central metal is $0.52 \mathrm{eV}$ less than the average change for $\left[\mathrm{MO}_{2}(\mathrm{CN})_{4}\right]^{2}$, indicating a trend opposite of that postulated here. Also, the calculated electron density pictures of the LUMO

(a)

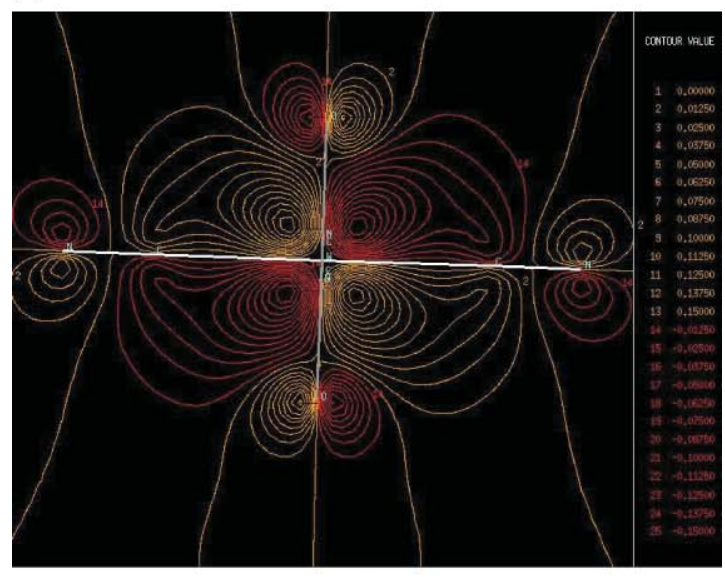

$\left[\mathrm{WO}_{2}(\mathrm{CN})_{4}\right]^{4-}$

(b)

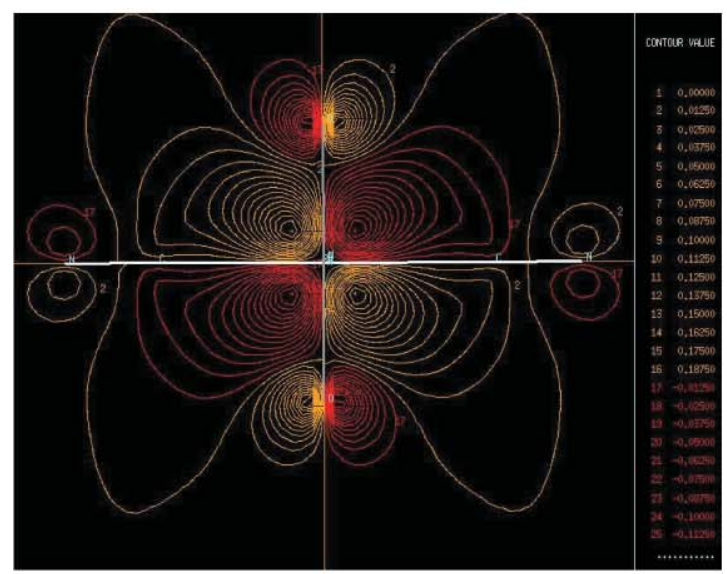

$\left[\mathrm{ReO}_{2}(\mathrm{CN})_{4}\right]^{3-}$

(c)

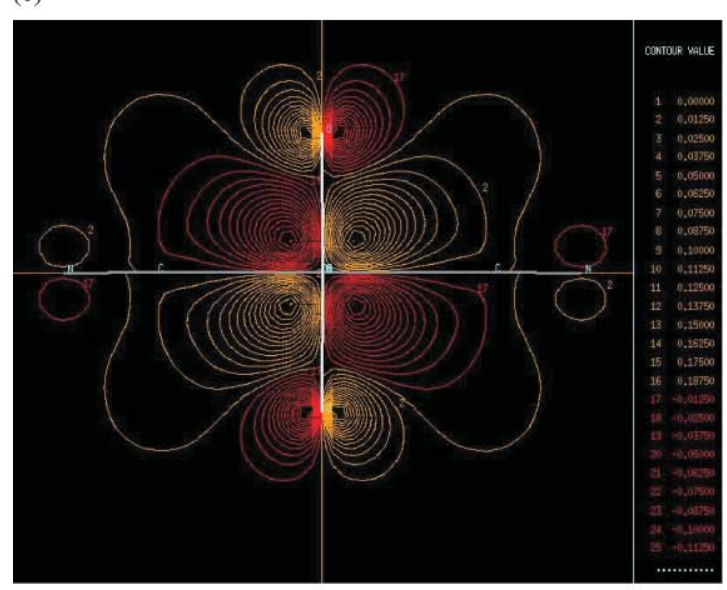

$\left[\mathrm{OsO}_{2}(\mathrm{CN})_{4}\right]^{2-}$

Fig. 2 Electron density pictures of the $e_{g}(x z, y z)$ orbitals calculated with $\mathrm{B}$-LYP for $\mathrm{MO}_{2}(\mathrm{CN})_{4}$ with $\mathrm{M}=\mathrm{W}, \mathrm{Re}$, and Os. orbitals (performed with MOLDEN ${ }^{39}$ ) indicate that there is slightly less bonding overlap between $\left(d_{x z}, d_{y z}\right)$ and $\pi^{*}(\mathrm{CN})$ for the complexes with higher charge (see, e.g., Fig. 2).

Another attractive possibility is that increasing the charge of the central metal atom decreases the amount of $d_{x y} \rightarrow \pi^{*}(\mathrm{CN})$ backbonding, thereby destabilizing the $\mathrm{b}_{2 \mathrm{~g}}(\mathrm{xy})$ orbital, and in turn decreasing $\Delta$. While variations in backbonding may affect the orbital splitting, they do not account for the observed trends. The metal oxidation states in these complexes range from IV-VI, and there is very little backbonding in complexes with such high oxidation states. Also, there is little variation in the $\mathrm{C}-\mathrm{N}$ bond distances in these complexes, suggesting only minor variations in $\pi^{*}(\mathrm{CN})$ populations. For $\left[\mathrm{MO}_{2}\left(\mathrm{NH}_{3}\right)_{4}\right]^{z}$, the average change in $E\left[\mathrm{~b}_{2 \mathrm{~g}}(\mathrm{xy})\right]$ per unit increase in the charge of the central metal atom is $0.79 \mathrm{eV}$ less than the average change for $\left[\mathrm{MO}_{2}(\mathrm{CN})_{4}\right]^{2}$. Such a small change in backbonding cannot be the primary cause for the large difference noted here.

We are left with one last explanation: For $\sigma$-only equatorial ligands such as $\mathrm{NH}_{3}$, the $\mathrm{b}_{2 \mathrm{~g}}(\mathrm{xy})$ orbital is virtually nonbonding. But for equatorial ligands such as $\mathrm{CN}^{-}$, there will be an antibonding interaction between the $d_{x y}$ orbital and cyanide $\pi$-orbitals. As the metal oxidation state increases, there will be more $\pi$-donation from the filled $\pi(\mathrm{CN})$ orbitals to the metal $d_{x y}$ orbital, thereby destabilizing $b_{2 g}(x y)$. Since the extent of $\pi$-donation increases significantly per unit increase in metal oxidation state, this trend could easily account for the relative destabilization of $\mathrm{b}_{2 \mathrm{~g}}(\mathrm{xy})$ in $\left[\mathrm{MO}_{2}(\mathrm{CN})_{4}\right]^{z}$ compared to $\left[\mathrm{MO}_{2}\left(\mathrm{NH}_{3}\right)_{4}\right]^{2}$. We conclude that variations in cyanide donor interactions with metal oxidation state account for the observed trends in ${ }^{1} \mathrm{~A}_{1 \mathrm{~g}}\left(\mathrm{~b}_{2 \mathrm{~g}}\right)^{2} \rightarrow{ }^{1} \mathrm{E}_{\mathrm{g}}\left(\mathrm{b}_{2 \mathrm{~g}}\right)^{1}\left(\mathrm{e}_{\mathrm{g}}\right)^{1}$ energies.

\section{Conclusion}

For complexes of the form $\left[\mathrm{MO}_{2}\left(\mathrm{NH}_{3}\right)_{4}\right]^{2}$, the energy of the ${ }^{1} \mathrm{~A}_{1 \mathrm{~g}}\left(\mathrm{~b}_{2 \mathrm{~g}}\right)^{2} \rightarrow{ }^{1} \mathrm{E}_{\mathrm{g}}\left(\mathrm{b}_{2 \mathrm{~g}}\right)^{1}\left(\mathrm{e}_{\mathrm{g}}\right)^{1}$ excitation increases with metal oxidation state, reflecting increased $\pi$-donation from the oxygen $p$ orbitals to the metal $\left(d_{\mathrm{xz}}, d_{\mathrm{yz}}\right)$ orbitals. For complexes of the form $\left[\mathrm{MO}_{2}(\mathrm{CN})_{4}\right]^{2}$, these energies remain roughly constant, as there is relatively greater destabilization of $\mathrm{b}_{2 \mathrm{~g}}(\mathrm{xy})$ when $\pi$-donors occupy equatorial positions.

\section{References}

1 C. J. Ballhausen and H. B. Gray, Inorg. Chem., 1962, 1, 111-122.

2 H. B. Gray and C. R. Hare, Inorg. Chem., 1962, 1, 363-368.

3 J. R. Winkler and H. B. Gray, Commun. Inorg. Chem., 1981, 1, 257-263.

4 J. R. Winkler and H. B. Gray, Inorg. Chem., 1985, 24, 346-355.

5 W. A. Nugent and J. M. Mayer, Metal-Ligand Multiple Bonds, WileyInterscience: New York, 1988.

6 V. M. Miskowski, H. B. Gray and M. D. Hopkins, Adv. Transition Met. Coord. Chem., 1996, 1, 159-186.

7 A. K. Mohammed and A. W. Maverick, Inorg. Chem., 1992, 31, 44414443.

8 I. Demachy and Y. Jean, Inorg. Chem., 1996, 35, 5027-5031.

9 R. A. Isovitsch, A. S. Beadle and F. R. Fronczek, Inorg. Chem., 1998, 37, 4258-4264.

10 E. Inego, E. Zangrando, S. Mestroni, G. Fronzoni, M. Stener and E. Alessio, J. Chem. Soc., Dalton Trans., 2001, 8, 1338-1346.

11 J. K. Grey, I. S. Butler and C. Reber, Can. J. Chem., 2004, 82, $1083-$ 1091.

12 J. K. Grey, I. S. Butler and C. Reber, Inorg. Chem., 2004, 43, 5103-5111.

13 R. Ahlrics, M. Bär, H. P. Baron, R. Bauernschmitt, S. Böcker, P. Deglmann, M. Ehrig, K. Eichkorn, S. Elliott, F. Furche, F. Haase, 
M. Häser, H. Horn, C. Hättig, C. Huber, U. Huniar, M. Kattannek, A. Köhn, C. Kölmel, M. Kollwitz, K. May, C. Ochsenfeld, H. Öhm, H. Patzelt, O. Rubner, A. Schäfer, U. Schneider, M. Sierka, O. Treutler, B. Unterreiner, M. von Arnim, F. Weigend, P. Weis and H. Weiss, TURBOMOLE V5-7, Quantum Chemistry Group, University of Karlsruhe, Karlsruhe, Germany (2004).

14 A. Schäfer, C. Huber and R. Ahlrichs, J. Chem. Phys., 1994, 100, 5829 5835.

15 D. Andrae, U. Haeussermann, M. Dolg, H. Stoll and H. Preuss, Theor Chim. Acta, 1990, 77, 123-132.

16 P. A. M. Dirac, Proc. R. Soc. London, Ser. A, 1929, 123, 714-733.

17 J. C. Slater, Phys. Rev., 1951, 81, 385-390.

18 S. H. Vosko, L. Wilk and M. Nusair, Can. J. Phys., 1980, 58, 1200-1211.

19 J. P. Perdew and Y. Wang, Phys. Rev. B, 1992, 45, 13244-13249.

20 A. D. Becke, Phys. Rev. A, 1988, 38, 3098-3100.

21 C. Lee, W. Yang and R. G. Parr, Phys. Rev. B, 1988, 37, 785-789.

22 J. P. Perdew, Phys. Rev. B, 1986, 33, 8822-8824.

23 J. P. Perdew, K. Burke and M. Ernzerhof, Phys. Rev. Lett., 1996, 77 , $3865-3868$

24 A. D. Becke, J. Chem. Phys., 1993, 98, 5648-5652.

25 A. Klamt and G. Schürmann, J. Chem. Soc., Perkin Trans. 2, 1993, (5), 799-805.
26 O. Treutler and R. Ahlrichs, J. Chem. Phys., 1995, 102, 346-354.

27 M. von Arnim and R. Ahlrichs, J. Chem. Phys., 1999, 111, 9183-9190.

28 F. Furche, J. Chem. Phys., 2001, 114, 5982-5992.

29 F. Furche and R. Ahlrichs, J. Chem. Phys., 2002, 117, 7433-7447.

30 P. Hummel, J. Oxgaard, W. A. Goddard, III and H. B. Gray, J. Coord. Chem., 2005, 58, 41-45.

31 P. Hummel, J. Oxgaard, W. A. Goddard, III and H. B. Gray, Inorg. Chem., 2005, 44, 454-458.

32 P. Hummel and H. B. Gray, Coord. Chem. Rev., submitted.

33 V. W. Day and J. L. Hoard, J. Am. Chem. Soc., 1968, 90, 3374-3379.

34 R. H. Fenn, A. J. Graham and N. P. Johnson, J. Chem. Soc. A, 1971, 2880-2883.

35 J. M. Malin, E. O. Schlemper and R. K. Murmann, Inorg. Chem., 1977, 16, 615-619.

36 W. Depmeier and S. A. Mason, Acta Crystallogr., Sect. B: Struct. Crystallogr. Cryst. Chem., 1978, B34, 920-922.

37 M. E. Kastner, M. J. Lindsay and M. J. Clarke, Inorg. Chem., 1982, 21, 2037-2040.

38 A. Abou-Hamdan, A. Roodt and A. E. Merbach, Inorg. Chem., 1998, 37, 1278-1288.

39 G. Schaftenaar and J. H. Noordik, J. Comput.-Aided Mol. Des., 2000, 14, 123-134. 